\title{
Productivity and Lexicalization in Pima Compounds*
}

\author{
PAMELA MUNRO and JASON RIGGLE \\ $U C L A$
}

\section{Introduction}

In this paper we describe aspects of nominal compounding in Pima, a UtoAztecan language of Arizona closely related to Tohono O'odham (Papago), discussing ways that compounds and "pseudo-compounds" are lexicalized and examining their pluralization, which is of particular interest because compound plural reduplication may appear in several (often discontinuous) locations. We close with a proposal for handling optional reduplication in a formal grammar.

\section{Data}

\subsection{Basic Reduplication and Stress}

The default pattern of pluralization (for both native words and loans) results in a copy of the initial consonant appearing immediately after the first vowel of the stem (Riggle 2003), as in (1). If copying the initial consonant alone would produce a dispreferred coda or cluster, then the initial consonant-vowel sequence is copied, as in (2):

$$
\text { C-copying: }
$$

$$
\text { 'lion’ mávit } \rightarrow \text { mámvit; 'orange’ nálash } \rightarrow \text { nánlash }
$$

(2) CV-copying:

$$
\begin{aligned}
& \text { 'rock' hódai } \rightarrow \text { hóhodai, but not *hóhdai } \\
& \text { 'peach' ñúlash } \rightarrow \text { ñúñulash but not * ñúñlash }
\end{aligned}
$$

Plural reduplication in Pima is extremely productive, although words like táatam 'tooth' that look inherently reduplicated generally lack plurals. ${ }^{1}$

Primary stress in Pima overwhelmingly falls on the initial syllable of the stem (cf., for Tohono O'odham, Fitzgerald 1997). However, object/possessive clitics like second person singular 'em-, though clearly included within the phonological word, are not stressed in words like 'em-'ú 'us 'your trees' (cf. 'ú'us 'trees').

\footnotetext{
${ }^{*}$ We are grateful to our wonderful Pima teacher, Virgil Lewis (originally from the Gila River Reservation in Arizona). We also thank Heriberto Avelino, Jeff Heinz, Brook Lillehaugen, Dave Schueler, Marcus Smith, and especially Colin Wilson, as well as audiences at BLS and LSA.

${ }^{1}$ Words borrowed from Spanish or English sometimes use borrowed plural morphology. We do not consider here a second non-singular form, the "distributive", which differs in both meaning and form from the plural (cf., e.g., Mathiot 1973: 36).
} 


\section{Productivity and Lexicalization in Pima Compounds}

\subsection{Basic Compounding}

Compounding in Pima is very productive, though the language has many lexicalized compounds (Riggle and Munro 2004). Pima has copulative (dvandva) compounds like màakai-páal 'doctor-priest' and determinative compounds like vàtopi-váinom 'fish-knife' (a knife shaped like, made out of, or adorned with fish, though not a knife used for eating or cutting fish, a knife suitable for use by fish, or a knife owned by a fish). ${ }^{2}$ Determinative compounds in Pima are modifier-head (right-headed): for example, compare vàtopi-váinom with vàinom-vátopi 'knifefish' (a fish shaped like, made out of, or adorned with a knife). Main stress in Pima compounds falls on the rightmost stem, while every other stem in the compound gets secondary stress. This pretonic secondary stress is significantly less than primary stress, but still greater than the (lack of) stress on the clitics discussed in section 1.1, as seen in examples like 'em-vàtopi-váinom 'your fish knife'. (We are not able to compare Pima pretonic secondary stress with the Tohono O'odham posttonic secondary stress reported by Fitzgerald (e.g., 1997).)

\subsection{Borrowed Words with Non-Initial Stress}

Some Pima borrowings (mainly from Spanish) are lexically specified for noninitial stress on the syllable that was stressed in the source language: màlóoma 'acrobat' (< Sp. maromo) and vilgóodii 'apricot' (< Sp. albaricoque) are prototypical examples, with a secondary stressed syllable before a stressed syllable with a long vowel. However, càpaliiya 'chaps' $(<$ Sp. chaparreras $)$, 'òvíspla 'bishop' (< Sp. obispo), and Mòndlái 'California' $(<\mathrm{Sp}$. Monterrey) show that in these borrowings more than one syllable may precede the main stress, which may fall on a short vowel or diphthong.

Such words have been discussed by Miyashita (2004), who terms their reduplication "collateral," and Fitzgerald $(1999,2004)$. Miyashita argues that stress need not be marked for these words, but falls predictably on the non-initial long vowel. We adopt a lexical account because words like 'bishop' and 'California' show non-initial stress on vowels that are not long. Words like 'apricot' illustrate another contrast between our analysis and Miyashita's: we assume that Pima indeed has a group of words that, like 'apricot', contain unstressed (final) long vowels. Following Saxton, Saxton, and Enos (1983), but contra, e.g., Zepeda (1983), we recognize only two degrees of vowel length for Pima. By our analysis, final short $i$ is devoiced following most consonants, and underlying final long $i$ surfaces as a short voiced vowel.

\section{Multiple Plural Marking in Compounds}

Multiple plural marking in copulative compounds occurs throughout Romance languages (Olsen 2001), as well as in English, when the first element of the compound has an irregular plural (Baker and Bobaljik 2002:61), as in (3):

\footnotetext{
${ }^{2}$ Pima does not have "possessive" nominal compounds of the grey-beard or blue-hair type.
} 
(3)
(Spanish) 'actor-dancer'
actor-bailarín
actores-bailarines
(Portuguese) 'actor-producer'
actor-encenador
(English)
'gentleman-farmer'
gentleman-farmer
actores-encenadores
gentlemen-farmers

Pima similarly marks both elements of copulative compounds with plural morphology, as in (4):

(Pima)

'doctor-priest'

màakai-páal

màmakai-pápal

In fact, however, Pima can mark both elements of all compound words with reduplication. Comparable reduplicative patterns occur in Mandarin (cf. Feng 2003) and in Sino-Korean "consecutive reduplication" (Chung 1999:170). Each stem of a plural compound may be reduplicated, but at least one must be, meaning that a two-part compound like vàtopi-váinom 'fish-knife' may have three plurals, one with both stems reduplicated (vàptopi-vápainom), one with only the first stem reduplicated (vàptopi-váinom), and one with only the second stem reduplicated (vàtopi-vápainom). Our consultant, Virgil Lewis, reports no difference in meaning among plural variants like those listed in (5), and generally only memory limits the number of plurals he volunteers.

\begin{tabular}{|c|c|c|}
\hline gloss and etymology & singular & plural forms \\
\hline 'bridge' (tree-road) & 'ùs-vóog & 'ùus-vópog, 'ùus-vóog, 'ùs-vópog \\
\hline 'church' (mass-house) & mìsh-kíi & mìmsh-kiik, mìmsh-kii, mìish-kíik \\
\hline 'onion soup' (onion-soup) & sìvol-sóoba & sìsvol-sósba, sìsvol-sóoba, sìvol-sósba \\
\hline 'peso' (Mexican-dollar) & Jùukam-píish & $\begin{array}{l}\text { Jùujkam-píipsh, Jùujkam-píish, } \\
\text { Jùukam-píipsh }\end{array}$ \\
\hline 'peyote' (coyote-plant.type) & bàn-nód:adag & $\begin{array}{l}\text { bàban-nónd:adag, bàban-nód:adag, } \\
\text { bàn-nónd:adag }\end{array}$ \\
\hline 'tamarack' (salt-tree) & 'ònk-'ús & 'ò'onk-'u'us, 'ò'onk-'ús, 'ònk-'ú'us \\
\hline 'uvula' (throat-bell) & bà'itk-kámpañ & $\begin{array}{l}\text { bàba'itk-kákampañ, bàba'itk-kámpañ, } \\
\text { bà'itk-kákampañ }\end{array}$ \\
\hline 'wagon' (tree-car) & 'ùs-kálit & 'ù’us-káklit, 'ù'us-kálit, 'ùs-káklit \\
\hline
\end{tabular}

We will come back to the variation among plural forms in section 5 below.

\section{Pseudo-Compounds}

Pima borrowed words with non-initial stress (section 1.3) may indicate their plural by reduplicating both the initial syllable and the stressed vowel (cf. Saxton, Saxton, and Enos (1983:xvi) for Papago): e.g., màmlóloma 'acrobats'. However, such words typically have more than one plural form, following the same pattern of multiple reduplication that we saw with the compounds in (5). Either or both of the secondary and main stressed portions of the word may reduplicate to indicate the plural, as in (6), again with no reported difference in meaning: 


$$
\text { 'acrobat' màlóoma } \rightarrow \text { 'acrobats' màmlóloma, màmlóoma, màlóloma }
$$

Other than compounds, borrowed words of this type are the only uninflected Pima words with non-initial primary stress, the only words that reduplicate more than one syllable of the base, and the only words that regularly have more than one plural. The pattern of variable multiple plural marking in these borrowings can be attributed to the fact that they have non-initial primary stress. Because this property is unique to compounds in the native vocabulary these words have been reanalyzed as "pseudo-compounds," despite their having only one semantic head (Riggle and Munro 2004).

Following the pseudo-compound analysis, we separate the two parts of such words, each of which behaves as a (pseudo-)stem, with a hyphen (just as though they were ordinary native compounds), as in (7). (In this we follow Saxton, Saxton, and Enos (1983), who use the hyphen as a diacritic to indicate that exceptional stress occurs on the following vowel.)

\begin{tabular}{|c|c|c|}
\hline gloss and etymology & singular & plural forms \\
\hline 'apricot' $(<$ Sp. albaricoque $)$ & vil-góodii & $\begin{array}{l}\text { vìpil-gógodii, vìpil-góodii, } \\
\text { vil-gógodii }\end{array}$ \\
\hline ‘bishop’ (< Sp. obispo) & 'ò-víspla & $\begin{array}{l}\text { 'ò o-vípispla, ’ò o-víspla, 'ò- } \\
\text { vípispla }\end{array}$ \\
\hline 'blueing’ (< Sp. anil) & 'à-ñiil & 'à'a-ñiñil, ’’̀'a-ñiil, ’à-ñiñil \\
\hline 'chaps' $(<$ Sp. chaparreras $)$ & càpa-líiya & càcpa-líliya, càcpa-líiya, càpa-líliya \\
\hline ‘clown' $(<$ Sp. payasa $)$ & pà-yáasa & pàp-yáyasa, pàp-yáasa, pà-yáyasa \\
\hline 'dove' $(<$ Sp. paloma $)$ & pà-lóoma & pàp-lóloma, pàp-lóoma, pà-lóloma \\
\hline 'emcee’ (< Sp. fiestero) & pìas-tíilo & piaps-títilo, piaps-tíilo, pìas-títilo \\
\hline 'gallon' $(<$ Sp. galón $)$ & và-lóon & vàp-lólon, vàp-lóon, và-lólon \\
\hline 'glass' (< Sp. limeta) & lì-míida & lìl-mímida, lìl-míida, lì-mímida \\
\hline 'pistol' $(<$ Sp. pistola $)$ & pìs-tóolii & pìps-tótolii, pìps-tóolii, pìs-tótolii \\
\hline 'pie' (< Sp.pastel) & pàs-tíil & pàpas-títil, pàpas-tíil,pàs-títil \\
\hline 'vest' $(<$ Sp. chaleco $)$ & cà-líigo & càc-líligo, càc-líigo, cà-líligo \\
\hline 'sheriff' $(<$ Sp. cherife $<$ Eng. $)$ & cà-líihi & càc-lílihi, càc-líihi, cà-lílihi \\
\hline
\end{tabular}

As (7) shows, when the second element of the pseudo-compound is reduplicated, length corresponding to the stress in the Spanish source word is lost. Plurals like vipil-gógodii and 'à-ñiñil with short stressed vowels show non-initial stress which is not dependent on non-initial vowel length.

Parallel analyses of loanwords following native morphological patterns occur in many languages: for example, Swahili kitabu 'book', borrowed from Arabic $k i t a a b$, is analyzed as $k i$-tabu, a member of noun class 7-8, with plural vi-tabu (Tom Hinnebusch and Leston Buell, p.c.). Similarly, Martin (2004) shows that French loans into Malagasy with the same prosodic patterns as compounds in the native lexicon show exceptional compound-like behavior in reduplication.

It would certainly be possible to formulate an analysis of multiple plural 
marking in these loans because of their stress, rather than morphological reanalysis, but this approach ignores the existence of precisely similar multiple plural marking in compounds. Claiming that these two patterns of optional multiple reduplication have unrelated motivations, one prosodic and the other morphological, misses a major generalization. Alternatively, attributing both patterns to prosody and not morphology ignores the connection between multiple marking in Pima compounds and multiple marking in compounds crosslinguistically. Thus, the pseudo-compound analysis is not only simpler but also significantly more illuminating from a cross-linguistic perspective.

\section{Lexicalization of Compounds and Pseudo-Compounds}

Many Pima compounds illustrate different processes of lexicalization and reanalysis. For example, the meaning of many compounds, including some of those in (5), is not derived componentially. The same conventionalization is confirmed by Saxton, Saxton, and Enos (1983), who list Tohono O'odham equivalents of many of our examples.

Although possessive interpretations for compounds like vàtopi-váinom 'fishknife' are not possible, there are possessive compounds whose second element is semantically inalienable with lexicalized metaphorical interpretations:

\begin{tabular}{lll}
\hline gloss and etymology & singular & plural \\
\hline 'baby coyote' (coyote-child) & bàn-mád & bàaban-máamad \\
'butter' (Chinese.person-brain) & cìino-'oág & (no plural) \\
'pipe cutter' (monkey-tail) & càango-báhi & càcango-báabhai \\
'saddle horn' (saddle-head) & pùust-mó'o & pùpst-móom \\
\hline
\end{tabular}

Reduplicated forms in compounds may differ from those of the corresponding independent words. The two stems that combine to form the compound 'small dragonfly sp.' in (9), múuki 'corpse' and jíviadam 'arriver', each have suppletive plurals, but in the compound regular plurals emerge, parallel to the behavior of English lexicalized compounds like Toronto Maple Leafs:

$$
\begin{aligned}
& \text { 'small dragonfly sp.' mùuki-jíviadam } \\
& <\text { múuki 'corpse' (pl. kó 'i) + jíviadam 'arriver' (pl. dádakam) } \\
& \rightarrow \text { pl. mùmuki-jíjiviadam but not *kò'i-dádakam }
\end{aligned}
$$

The most striking change that accompanies the lexicalization of compounds is the reanalysis of their atypical non-initial stress. This reanalysis is especially frequent with pseudo-compounds: their first syllable acquires native-like primary stress while stress (and consequently length) on the originally stressed non-initial syllable is lost. Nativized words (10) reduplicate only their initial syllable: 
(10)

\begin{tabular}{|c|c|c|}
\hline gloss and etymology & singular & plural \\
\hline 'bell' (< Sp. campana) & kámpañ & kákampañ \\
\hline 'candle' $(<$ Sp. candela $)$ & kánjul & kákanjul \\
\hline 'car' $(<$ Sp. carreta $)$ & kálit & káklit \\
\hline 'drum' (< Sp. tambor) & támbol & tátambol \\
\hline 'gun' (< Sp. arcabuz) & gávos & gágvos \\
\hline 'horse' (< Sp. caballo) & káviu & kákaviu \\
\hline 'paper' $(<$ Sp. papel $)$ & tápial & tátpial \\
\hline 'peach' (< Sp. durazno) & ñúlash & ñúñulash \\
\hline ‘soap' (< Sp. jabón $)$ & shávoñ & sháshvoñ \\
\hline 'soldier' $(<$ Sp. soldado $)$ & shóndal & shóshondal \\
\hline 'wagon tongue' $(<$ Sp. timón $)$ & címoñ & cícmoñ \\
\hline 'week' $(<$ Sp. domingo $)$ & dómig & dódmig \\
\hline
\end{tabular}

Although the words in (10) are documented only in the reanalyzed form with initial stress, there are numerous other borrowed words that alternate (for a single speaker, such as our Pima consultant; between speakers; or between Pima and Tohono O'odham) between a pseudo-compound form with non-initial stress (like those in (7)) and a reanalyzed initially stressed form (like those in (10)), thus supporting the notion of a gradual historical reanalysis of all such forms. ${ }^{3}$ In (11), unmarked forms are Pima, and Tohono O'odham words (from Saxton, Saxton, and Enos 1983) ${ }^{4}$ are preceded by TO.

\begin{tabular}{lll}
\hline gloss and etymology & pseudo-compound & nativized form \\
\hline 'bonnet' $(<$ Sp. cucurucho $)$ & TO kù-lúuji & kúluji \\
'cook' $(<$ Sp. cocinero $)$ & kòs-ñéel & kósñel \\
'godfather' $(<$ Sp.padrino $)$ & pò-líina & póolina \\
'lining' $(<\mathrm{Sp}$. abolla $)$ & TO 'à-póola & 'ápola \\
'palomino' $(<\mathrm{Sp})$. & TO pàl-míito & pálmito \\
'saddle blanket' $(<$ Sp. sudadero $)$ & shù-víijel & shúvijel \\
'sock' $(<$ Sp. calcetín $)$ & TO kàl-siido & kálsido \\
'tobacco' $(<$ Sp.tabaco $)$ & TO tà-wáago & távako \\
\hline
\end{tabular}

Again, only the initial primary stressed syllable of nativized loans is reduplicated.

(12) kòs-ñél 'cook' (pseudo-compound) $\rightarrow$ pl. kòks-ñél, kòks-ñéñel, kòs-ñéñel kósñel 'cook' (nativized) $\rightarrow$ pl. kóksñel; *kóksñeñel, *kósñeñel

In a few cases, the reanalyzed form with initial stress may be anticipated by

\footnotetext{
${ }^{3}$ It is possible that more recently speakers have re-borrowed some words as pseudo-compounds, beginning the cycle of nativization again.

${ }^{4}$ Here and below we have adapted the Saxton, Saxton, and Enos (1983) orthography to match ours; note that TO $w$ corresponds to Pima $v$.
} 
speakers' reluctance to mark a non-initial stressed syllable for plural:

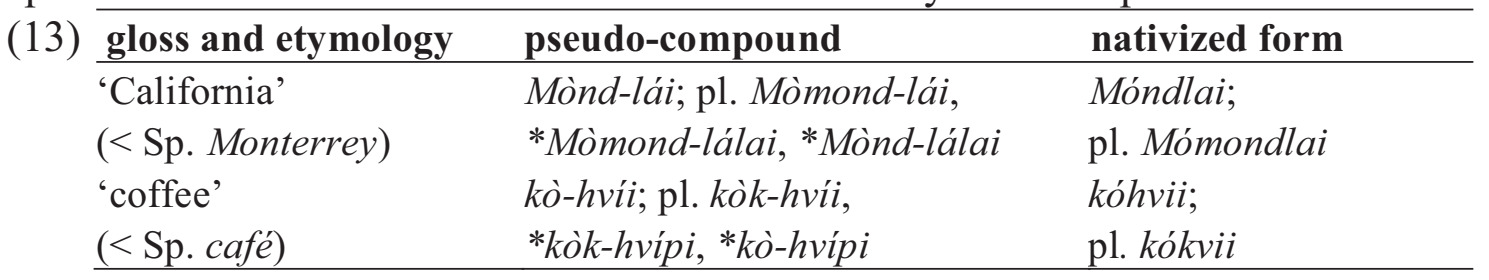

Undoubtedly, one of the things that speeds the reanalysis of pseudocompounds is the fact that they have only one semantic head. In some cases, speakers may folk-etymologize pseudo-compounds (even bilingually) so that they more clearly contain two heads. As (14) shows, the Spanish Noche Buena 'Christmas Eve' was originally borrowed as Nòji-wíino (Nòji-víino in earlier Pima), which was presumably a semantically opaque pseudo-compound for most speakers. In current Pima, this is Neòsh-víino; Neósh means 'God' (itself a loan from Spanish Dios), and Mr. Lewis has suggested that 'Christmas Eve' comes from Spanish Dios viene 'God comes'.

(14) Sp. Noche Buena 'Christmas Eve' (lit. 'good night') > earlier Pima and current TO Nòji-wíino > current Pima Neòsh-víino

The less clear the evidence for two semantic heads, the more likely the reanalysis, and indeed, most cases of reanalyzed compound stress that we have identified are in loanwords. However, the same process occurs in native compounds ${ }^{5}$ like (15), which is presented with Mr. Lewis's suggested etymology:

$$
\begin{aligned}
& \text { hoáshom 'deerskin medicine bag' < hoá 'basket' + shóoma 'sewn item' } \\
& \rightarrow \text { pl. hoáhashom }
\end{aligned}
$$

Alternatively, Saxton, Saxton, and Enos (1983) relate this word to huái 'deer'. Clearly, once such a word is relexicalized with its original compound stress reanalyzed, its etymological word structure is less accessible. Like the nativized pseudo-compounds, reanalyzed native compounds have only one plural.

\section{The Productivity of Compounding}

Pima compounds may also be productively formed with more than two stems, the last of which receives primary stress. Since each stem may optionally be marked with plural reduplication, there is extensive variation. In general, if there are $\boldsymbol{n}$ stems, there are $2^{n}-1$ plural variants. Thus, a compound with three stems will have seven plurals, varying by whether three, two, or just one stem is reduplicated.

\footnotetext{
5 Pima verbs present many more examples of old compounds with reanalyzed stress. Marcus Smith has provided us with examples like gátwua 'to shoot' (< gáat 'gun' plus wuá 'to do') and gógswua 'to sleep around, be slutty' (< gógs 'dog' plus wuá).
} 


\title{
Productivity and Lexicalization in Pima Compounds
}

(16)

\author{
['us-kàlit]-[váinom] [tree-car]-[knife] 'wagon-knife' (three stems) \\ pls. - all three reduplicants: \\ ['u'us-kàkalit]-[vápainom]; \\ two reduplicants: \\ ['u'us-kàkalit]-[váinom], ['u'us-kàlit]-[vápainom], ['us-kàkalit]-[vápainom]; \\ one reduplicant: \\ ['u'us-kàlit]-[váinom], ['us-kàlit]-[vápainom], ['us-kàkalit]-[váinom]
}

Note that pseudo-compound loans show the same pattern of optional reduplication in compounds as they do in isolation (so the stems we refer to may be pseudostems). Thus, even if there aren't $\boldsymbol{n}$ distinct morphemes, there can still be $2^{n}-1$ plurals in apparent free variation. With four (pseudo-)stems a compound will have 15 plurals, as in (17).

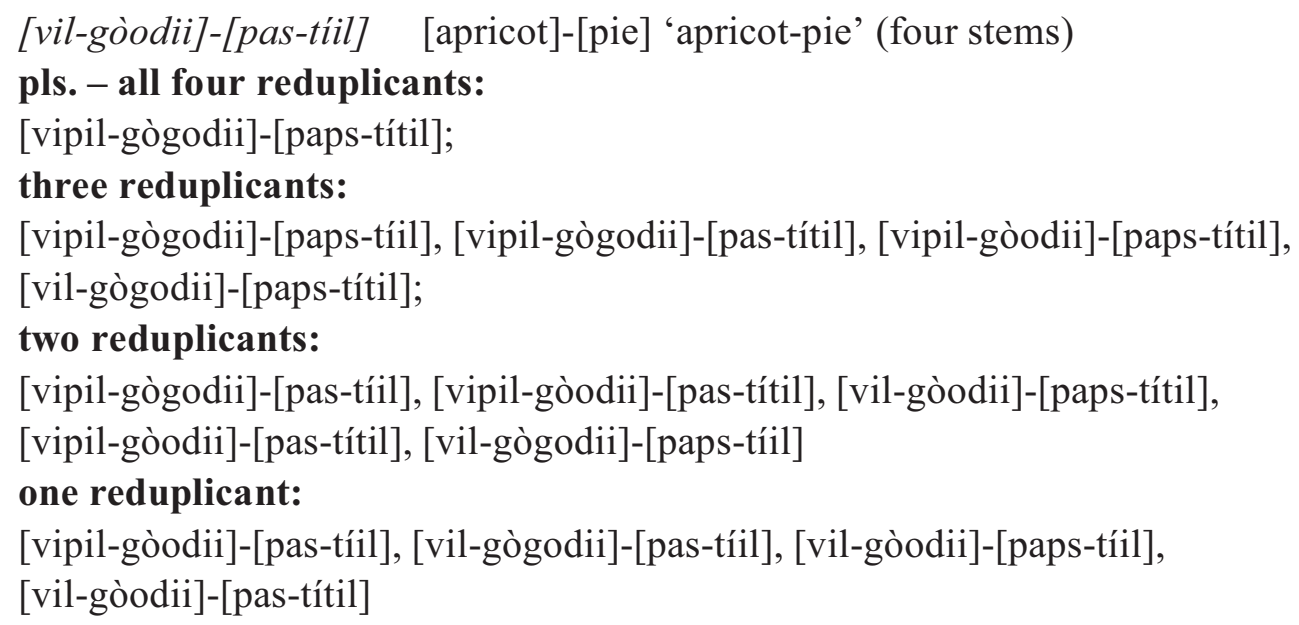

The basic generalization is that the initial consonant of each stem (or pseudostem) may optionally be reduplicated but at least one stem must be marked with plural morphology in every plural compound. Thus, with five stems, a compound will have 31 plural forms. This is illustrated in (18).

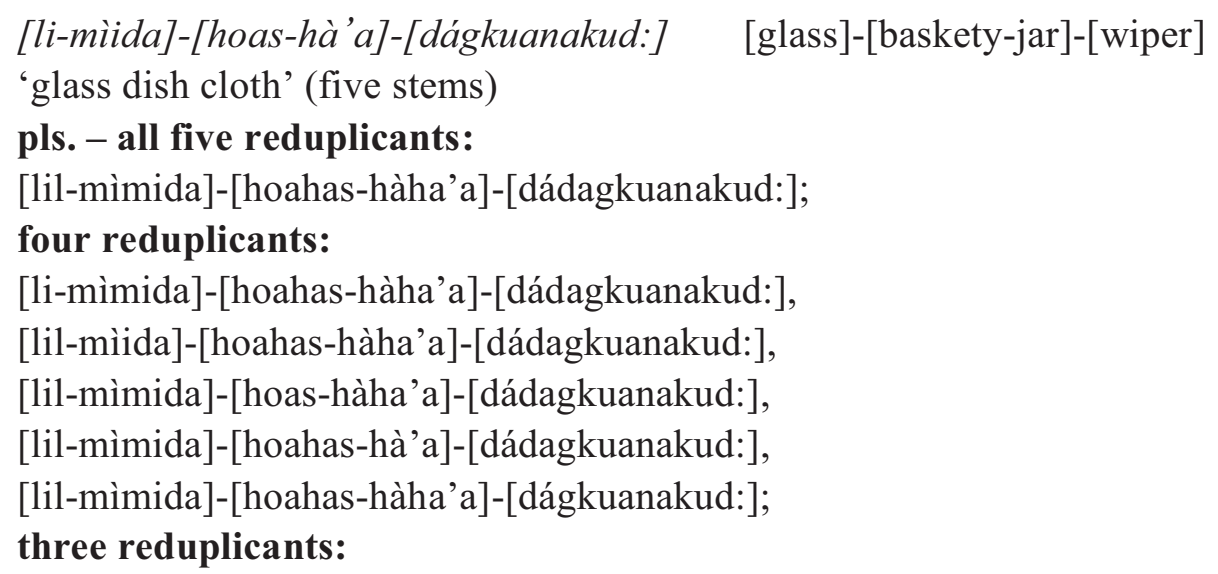




\begin{abstract}
[lil-mìmida]-[hoahas-hà'a]-[dágkuanakud:], [lil-mìmida]-[hoas-hàha'a]-[dágkuanakud:], [lil-mìmida]-[hoas-hà'a]-[dádagkuanakud:], [lil-mìida]-[hoahas-hàha'a]-[dágkuanakud:], [lil-mìida]-[hoahas-hà'a]-[dádagkuanakud:], [lil-mìida]-[hoas-hàha'a]-[dádagkuanakud:], [li-mìmida]-[hoahas-hàha'a]-[dágkuanakud:], [li-mìmida]-[hoahas-hà'a]-[dádagkuanakud:], [li-mìmida]-[hoas-hàha'a]-[dádagkuanakud:], [li-mìida]-[hoahas-hàha'a]-[dádagkuanakud:];

two reduplicants:
\end{abstract}

[lil-mìmida]-[hoas-hà'a]-[dágkuanakud:], [lil-mìida]-[hoahas-hà'a]-[dágkuanakud:]

[lil-mìida]-[hoas-hàha'a]-[dágkuanakud:], [lil-mìida]-[hoas-hà'a]-[dádagkuanakud:], [li-mìmida]-[hoahas-hà'a]-[dágkuanakud:], [li-mìmida]-[hoas-hàha'a]-[dágkuanakud:], [li-mìmida]-[hoashà'a]-[dádagkuanakud:], [li-mìida]-[hoahas-hàha'a]-[dágkuanakud:], [li-mìida]-[hoahas-hà'a]-[dádagkuanakud:], [li-mìida]-[hoas-hàha'a]-[dádagkuanakud:]; one reduplicant:

[lil-mìida]-[hoas-hà'a]-[dágkuanakud:], [li-mìmida]-[hoas-hà'a]-[dágkuanakud:], [li-mìida]-[hoahas-hà'a]-[dágkuanakud:], [li-mìida]-[hoas-hàha'a]-[dágkuanakud:], [li-mìida]-[hoas-hà'a]-[dádagkuanakud:]

Compounds that include apparently inherently reduplicated words like táatam 'tooth' or Móomli 'Mormon' that lack a plural (section 1.1), such as Jùukamtàatam-máakai (Mexican-tooth-doctor) 'Mexican dentist' or [Mòomli]-['ò-víspla] (Mormon-bishop) 'Mormon bishop' have fewer plural variants than would be expected from their number of stems. Although it contains three stems, for example, 'Mexican dentist' has three plurals, not seven: Jùujkam-tàatammámakai, Jùujkam-tàatam-máakai, and Jùukam-tàatam-mámakai.

\title{
6. A Formal Account of Local Optionality
}

The multiple marking of plurals in compounds can be derived with a positionally indexed Base-Reduplicant faithfulness constraint (cf. Nelson 2003, Riggle 2003).

BASE/REDUPLICANT-MAX-C : $^{\text {: }}$

The initial consonant of each stem must be copied in reduplication.

We can restrict multiple reduplication with a countervailing force that penalizes 
surface forms with multiple exponents of the plural morpheme: ${ }^{6}$

*Multiple-Exponents $(*$ MultEx):

Multiple expression of a single input morpheme is penalized.

Free variation in plural reduplication in Pima shows what Vaux (2003) calls "sequential optionality." This presents a challenge for OT analyses of variation that rely on variation in constraint ranking to select varied output forms (Anttila 1997, Boersma and Hayes 2001). Because there is only one ranking per derivation a sort of all-or-nothing behavior is predicted. This is illustrated in (21) below. ${ }^{7}$

\begin{tabular}{|l|c|c|}
\hline \multicolumn{1}{|c|}{ RED+miish+kii ‘church’ } & *MULTEX & B/R-MAx-C 1 \\
\hline a. $(\varpi)$ mìmsh-kíi & $*$ & \\
\hline b. $(\varpi)$ mìmsh-kíi & & $*$ \\
\hline c. $(\varpi)$ mìish-kíi & & $*$ \\
\hline d. mìish-kíi & & $* * !$ \\
\hline
\end{tabular}

If $\mathrm{B} / \mathrm{R}-\mathrm{MAX}-\mathrm{C}_{1}$ is ranked above *MultEX, candidate a is selected and each stem is marked with reduplication. With the inverse ranking, candidate $\mathrm{b}$ or $\mathrm{c}$ will win and only one stem will be reduplicated. Reranking the constraints predicts either that all of the stems should will show reduplication or that only one stem will show reduplication. This is problematic when forms with more than two stems are considered because there is no way to generate an "intermediate" alternative like the one in (22b) below in which only a few of the stems show reduplication.

\begin{tabular}{|ll||c|c|}
\hline \hline \multicolumn{2}{|c||}{ RED+vil-gòodii-pas-tíil 'apricot-pie' } & $*$ MULTEX & $\mathrm{B} / \mathrm{R}-\mathrm{MAX}-\mathrm{C}_{1}$ \\
\hline \hline a. & vil-gòodii-pas-títil & & $* * *$ \\
\hline b. $\quad$ i & vil-gògodii-pas-títil & $* !$ & $* ! *$ \\
\hline c. $\quad$ vipil-gògodii-paps-títil & $* * *$ & \\
\hline
\end{tabular}

To generate candidates like (22b), we will borrow the notion of optionality from rule-based grammars, but because OT constraints embody phonological principles, we won't simply make them turn off some of the time. Instead, following Boersma and Hayes (2001) and Anttila (1997), we'll generate the different outputs in free variation by reranking the constraints in the grammar. The tricky part is capturing the local character of the optionality. To do this, we allow constraints to be reranked within a single derivation rather than just between derivations. In (23) we represent B/R-MAX-C $C_{1}$ twice, once above

\footnotetext{
${ }^{6}$ Alternatively, we might pit B/R-MAX-C ${ }_{1}$ against *STRUCTURE (Zoll 1993) or a constraint barring discontinuous expression of morphemes. Our focus here is on the interaction between these drives, not on capturing the general cross-linguistic dispreference for multiple expression of morphemes.

${ }^{7}$ For concreteness we assume that Pima reduplicants (boldfaced in the examples below) appear immediately to the right of material they copy (following Riggle 2003; section 1.1), but note that no aspect of our analysis hinges crucially on this assumption.
} 
*MulTEx and once below it.

\begin{tabular}{|c|c|c|c|}
\hline $\begin{array}{l}\text { 'church' } \\
\text { RED+miish+kii }\end{array}$ & $\begin{array}{c}\mathbf{A} \\
\text { B/R-MAX-C } \\
\end{array}$ & *MultEx & $\begin{array}{c}\text { B } \\
\text { B/R-MAX-C } \\
\end{array}$ \\
\hline a. mìmsh-kíik & & $*$ & \\
\hline b. mìmsh-kíi & $(*)$ & & $($ ) \\
\hline c. mìish-kíik & $(*)$ & & ( ) \\
\hline d. mìish-kíi & $(*)(*)$ & & ()() \\
\hline
\end{tabular}

In this tableau, potential loci for the violations of the optionally ranked constraint are enclosed in parentheses. Each violation must be assigned to exactly one of its potential locations.

In (23) we've illustrated the case where all of the B/R-MAX- $\mathrm{C}_{1}$ violations are assigned to the A column. Candidates $\mathrm{b}$ or $\mathrm{c}$ can win if the violation marks for $\mathrm{d}$ and $\mathrm{c}$ or $\mathrm{b}$ respectively are demoted to column $\mathrm{B}$. But candidate $\mathrm{d}$ can also win if its violations are demoted to column $\mathrm{B}$ and the violations for $\mathrm{b}$ and $\mathrm{c}$ are left in column A. This is problematic because the selection of candidate $d$ is not motivated by *MULTEX, merely arising as an artifact of the optional ranking. ${ }^{8}$

The key to avoiding this type of problem is to make sure that a given violation is treated the same way across the candidates. To do this we extend the segmental indexing of correspondence theory (McCarthy and Prince 1995) to the violations themselves, giving each star the index of the segment that caused it, as in (24): ${ }^{9}$

\begin{tabular}{|c|c|c|c|}
\hline $\begin{array}{l}\text { 'church' } \\
\mathrm{RED}+\mathrm{m}_{1} \mathrm{ii}_{2} \mathrm{sh}_{3}+\mathrm{k}_{4} \mathrm{ii}_{5}\end{array}$ & $\begin{array}{c}\mathrm{A} \\
\mathrm{B} / \mathrm{R}-\mathrm{MAx}-\mathrm{C}_{1} \\
\end{array}$ & *MULtEX & $\begin{array}{c}\text { B } \\
\text { B/R-MAx-C } \\
\end{array}$ \\
\hline a. mìmsh-kíik & & $*$ & \\
\hline b. mìmsh-kíi & $(*)_{4}$ & & ()$_{4}$ \\
\hline c. mìish-kíik & $(*)_{1}$ & & ()$_{1}$ \\
\hline d. $\widetilde{O}^{*}$ mìsh-kíi & $(*)_{1}(*)_{4}$ & & ()$_{1}()_{4}$ \\
\hline
\end{tabular}

Thus, the violations of $\mathrm{B} / \mathrm{R}-\mathrm{MAx}-\mathrm{C}_{1}$ are either indexed with 1 for the initial consonant of the first stem or with 4 for the initial consonant of the second stem. Candidate $d$ shares an index 4 violation with candidate $b$ (because they both fail to copy the initial consonant of the second stem) and also shares an index 1 violation with candidate $\mathrm{c}$ (because they both fail to copy the initial consonant of the first stem). In this sense the violations incurred by candidate $d$ are a true superset of those incurred by either b or c.

Using indices on the violations allows us to formulate the following principle on evaluation with optionally ranked constraints:

\footnotetext{
${ }^{8}$ Candidate d could be ruled out by REALize MORPHEME (cf. Kurisu 2001), but we still need to prevent candidates with unmotivated violations from being selected by optional reranking.

For constraints that are violated by a sequence of segments, it doesn't matter which segment's index is used for the violations so long as the choice is consistent across candidates.
} 


\section{Productivity and Lexicalization in Pima Compounds}

\section{CONSISTENCY OF Evaluation:}

In choosing how to assign the violations of a given optionally ranked constraint, all violations with the same index must be assigned to the same column.

If the CONSISTENCY OF EVALUATION principle is obeyed, then every assignment of the violations of the optionally ranked constraint $\mathrm{B} / \mathrm{R}-\mathrm{MAX}-\mathrm{C}_{1}$ will yield an attested plural variant as a potential optimal output. For instance, in (26), we've shown the case where every violation of the optionally ranked constraint has been assigned to the A column: this selects candidate $\mathrm{f}$ (where each stem is reduplicated). Demoting some or all of the violations to column B selects different candidates as optimal.

\begin{tabular}{|c|c|c|c|}
\hline $\begin{array}{l}\text { 'apricot-pie' } \\
\text { RED }+v_{1} \text { il-g } g_{4} \text { òodii- } p_{8} \text { as-t } t_{11} \text { íl }\end{array}$ & $\begin{array}{c}\text { A } \\
\text { B/R-MAX-C } \\
\end{array}$ & $\begin{array}{c}\text { *MULT } \\
\text { EX }\end{array}$ & $\begin{array}{c}\text { B } \\
\text { B/R-MAX-C } \\
\end{array}$ \\
\hline a. $\sigma$ vil-gòodii-pas-títil & $(*)_{1}(*)_{4}(*)_{8}$ & & ()$_{1}()_{4}()_{8}$ \\
\hline b. vil-gògodii-pas-títil & $(*)_{1}(*)_{8}$ & $*$ & ()$_{1}()_{8}$ \\
\hline c. vipil-gòodii-pas-títil & $(*)_{4}(*)_{8}$ & $*$ & ()$_{1}()_{8}$ \\
\hline d. vipil-gògodii-paps-tíil & $(*)_{11}$ & $* *$ & ()$_{11}$ \\
\hline e. vipil-gòodii-paps-títil & $(*)_{4}$ & $* *$ & ()$_{4}$ \\
\hline f. vipil-gògodii-paps-títil & & $* * *$ & \\
\hline
\end{tabular}

\section{Summary}

In this paper we have presented a description of Pima compounding and pseudocompounding (by which borrowed words with anomalous non-initial stress are analyzed as compounds because of their similarity to native compounds). Both compounds and pseudo-compounds show variable reduplicative plural marking: while plural must be marked at some point, any number of the stems in a compound may be reduplicated. Certain older Pima compounds have various lexicalized features, and both pseudo- and native compounds may be regularized with non-compound initial stress. Finally, we've outlined a strategy for generating local optionality in Optimality Theory.

\section{References}

Anttila, Arto. 1997. Deriving variation from grammar: A study of Finnish genitives. In F. Hinskens, R. van Hout, and L. Wetzels, eds., Variation, Change and Phonological Theory, 35-68. Amsterdam: John Benjamins. Rutgers Optimality Archive ROA-63.

Baker, Mark, and Jonathan David Bobaljik. 2002. An introduction to morphology. Ms., Rutgers University and McGill University.

Boersma, Paul, and Bruce Hayes. 2001. Empirical tests of the gradual learning algorithm. Linguistic Inquiry 32:45-86. 
Chung, Chin Wan. 1999. Consecutive reduplication in Korean. Harvard Studies in Korean Linguistics VIII:88-101.

Feng, Guanjun Bella. 2003. Verb versus adjective reduplication in Mandarin. LSA.

Fitzgerald, Colleen M. 1997. O’odham Rhythms. Ph.D. diss., University of Arizona.

Fitzgerald, Colleen M. 1999. Loanwords and stress in Tohono O'odham. Anthropological Linguistics 41:193-208.

Fitzgerald, Colleen M. 2004. How many reduplications are there in Tohono O'odham? Workshop on American Indigenous Languages, Santa Barbara.

Martin, Andy. 2004. Pseudo-compounds in Malagasy. Southwest Optimality Theory Workshop, Santa Cruz.

Mathiot, Madeleine. 1973. A Dictionary of Papago Usage. Bloomington: Indiana University.

McCarthy, John. 1999. Sympathy, cumulativity and the Duke-of-York gambit. In K. Baertsch and D. A. Dinnsen, eds., Indiana University Working Papers in Linguistics 1: Optimal Green Ideas in Phonology, 57-91. Bloomington: IULC.

Miyashita, Mizuki. 2004. O'odham collateral reduplication. Workshop on American Indigenous Languages, Santa Barbara.

Nelson, Nicole. 2003. Asymmetric Anchoring. Ph.D. diss., Rutgers University.

Olsen, Susan. 2001. Copulative compounds: A closer look at the interface between syntax and morphology. In Geert Booij and Jaap van Marle, eds., Yearbook of Morphology 2000, 279-320. Dordrecht: Kluwer.

Riggle, Jason. 2003. Infixation in Pima reduplication and its theoretical consequences. LSA.

Riggle, Jason, and Pamela Munro. 2004. One morpheme-two reduplicants: Pseudo-compounds in Pima. LSA, http://www.bol.ucla.edu/ riggle/riggle MunroLSA04.pdf.

Saxton, Dean, Lucille Saxton, and Susie Enos. 1983. Papago/Pima-English, O'otham-Mil-gahn; English Papago/Pima, Mil-Gahn-O'otham Dictionary. Second ed., ed. by R. L. Cherry. Tucson: University of Arizona Press.

Vaux, Bert. 2003. Why the phonological component must be serial and rulebased. LSA.

Zepeda, Ofelia. 1983. A Papago Grammar. Tucson: University of Arizona Press.

Pamela Munro and Jason Riggle

Department of Linguistics, UCLA

Box 951543

Los Angeles, CA 90095-1543

munro@ucla.edu

riggle@humnet.ucla.edu 